(Житомирський державний університет імені Івана Франка)

\title{
МІФОТВОРЧІСТЬ В КОМУНІКАТИВНОМУ ПРОСТОРІ: ДО ПИТАННЯ КОНЦЕПТУАЛІЗАЦІЇ ПРОБЛЕМИ
}

Здійснено аналіз феномену міфотворчості, щзо відбувається в сучасній комунікації завдяки популярній літературі, кіномистецтву та анімаџї̈ тощзо. На основі розгляду змістового насичення таких понять, як "міфологізачія", "деміфологізація", "міфологія" та "міфізація", автор дійшов думки, щзо вони фіксують неоднакові явища при створенні чи поширенні міфів, в тому числі й новітніх міфів, які широко представленні в сучасному комунікативному просторі завдяки ЗМI, рекламі, масовій культурі та популярному мистецтвв, політичній діяльності різних інституцій сучасного суспільства.

Запропоновано розглядати міфотворчість свідомим продукуванням, створенням з боку людини конкретних новітніх міфів, точніше міфологем, наприклад з виробничих потреб в масовій культурі, популярному мистецтвві. Також стверджуємо, щзо на відміну від міфізації, міфотворчість має позитивне значення для духовного життя сучасного суспільства.

Стверджуємо, щзо однією із вагомих причин існування міфотворчості є людське бажання виходити за межі повсякденності, щоб уникнути нудьги, втоми і розважитися. Ще одним важливим ї̈ стимулом є прагнення відійти, хоча б на деякий час, від логіки утилітаризму, меркантилізму, яка активно пропагується в сучасному суспільстві.

Ключові слова: новітній міф, міфотворчість, міфологізачія, комунікативний простір, суспільна свідомість.

Актуальність теми дослідження. Поняття "міфотворчість", незважаючи на його вжиток у сучасній науковій літературі, ще не отримало однозначного трактування. Це пояснюється передусім тим, що цей соціальний феномен постає об'єктом вивчення не лише філософії чи теорій масової комунікації, а й багатьох інших наук (політології, культурології, етнографії, літературознавства тощо). У цих галузях наукового знання, крім того, має ужиток низки понять, дотичних до міфотворчості: міфології, міфічності і міфопоезису, міфологеми й неоміфу, що актуалізує необхідність його дослідження у міждициплінарній площині. А ще про необхідність його грунтовного аналізу свідчить й відсутність представленості зазначеного поняття у більшості фахових словниках за вказаними науковими напрямами. Крім того, фіксується декілька теоретичних позицій у його розумінні. Цим й зумовлюється потреба звернення до розгляду як змістового наповнення даного поняття, так і специфіки міфотворчості у сучасному комунікативному просторі, враховуючи потужний вплив новітніх міфів, продукованих ЗМІ, рекламою, соціальними комунікаціями і блогосферою, популярною літературою і кінематографом.

Мета дослідження полягає у спробі розлогого аналізу поняття міфотворчості задля обгрунтування його цінності при розгляді засад створення новітнього міфу (міфологеми) у сучасній рекламній практиці й 3МI.

Ступінь розробленості проблеми. Серед досліджень сучасного соціального міфу, особливостей його продукування різними засобами і причин широкого поширення треба зазначити, передусім, напрацювання: Р. Барта [1], О. Бондар [2], Л. Воєводіної [3], Н. Воронової [4], В. Дубіцької [5], Е. Кассірера [6], О. Поліщук [7], Р. Сапенької [8] та ін. На погляд О. Бондар, міфотворення в сучасному суспільстві стало засобом керування комунікацією соціальних суб'єктів через використання міфологічних образів або певного сюжету в комунікативному акті для розв'язання соціально важливого завдання [2]. Як вважає Р. Сапенько, підгрунтям кожного міфу, а новітній не є виключенням, виступає словесно окреслена в ньому історія, і зв'язок міфологізованої та естетичної свідомості відбувається через їх спільну перцептивну базу, зумовлену універсально-смисловим сприйняттям мови [8: 55-56]. Як наголошує В. Дубіцька, в наш час міф став вже не стільки засобом пізнання, розуміння і переживання людьми невідомого у світі, він сьогодні набуває часто вагомої ролі при прагненні "осмислення потоку життя", і це необхідно враховувати при розгляді причин теперішньої затребуваності міфу в соціумі. "Це надзвичайно важливо, оскільки в сучасній літературі "міфологічне" часто стає синонімом неправдивого, ілюзорного і тільки", - зазначає дослідниця [5: 120]. Затребуваність новітніх міфів, наприклад, в масовій літературі чи кіно, як вказує О. Поліщук, полягає не тільки у розвазі від міфу, а й "отриманні естетичної насолоди від зустрічі із ним..." [7: 62]. Крім того, вона зазначає таку причину створення новітніх міфів, як появу альтернативної історії чи альтернативної реальності, коли виникає незвична ситуація: створюється "альтернативна історія, в яку віриться охочіше, ніж у реальні проблеми й події" [7: 61].

Проте проблема відмінності явищ міфотворчості й міфізації ще не належно осмислена в сучасній 
філософській науці, що й зумовлює необхідність їх поглибленого аналізу.

Виклад основного матеріалу. Необхідно вказати, насамперед, на неоднозначність розуміння міфотворчості, як процесу, та оцінки його результатів з боку різних гуманітарних і соціальних наук.

Так, у "Великому тлумачному словнику української мови" воно трактоване доволі широко, а саме: як "створення міфів" [9: 533]. Однак у цьому контексті, як варто наголосити, поза увагою залишаються суб'єкти міфотворчості, особливо в сучасних умовах, та інструменти їі здійснення. А це не дає змоги встановлення мети подібної соціальної діяльності з боку конкретно-історичних спільнот, суспільних інституцій, професійних груп та ін.

Міфологія у "Філософському словнику" (автори видання - I. Андрущенко, О. Вусатюк, С. Лінецький та О. Шуба) розглядається процесом створення міфів у суспільстві, крізь призму якої й подається тлумачення поняття міфотворчості, як створення благоговійних, сакралізованих образів провідних сторін суспільного життя (держави, конкретної форми влади, власності, ринку, нації та ін.) [11: 564-565]. Як бачимо, тут акцентується, передусім, увага на позаісторичності цього соціального феномену, оскільки визнається його існування протягом дуже тривалого часу в культурі й духовному житті людства. А ще бачимо акцент на тому, що міфотворчість має цілком усвідомлений і прагматичний сенс для людини, що реалізовує соціальні, ідеологічні і, можливо, економічні чи політичні інтереси якоїсь соціальної групи (прошарку).

Звертається до міфотворчості й В. Скуратівський, розглядаючи їі в контексті природи й значення архаїчного міфу, міфологічного мислення. Треба зазначити, що ним вживається й поняття міфологізації, коли він розглядає розвиток сучасних наук, гуманітарних і природничих, стверджуючи про їх "своєрідну міфологізацію своїх проблем і предметів". Зокрема він стверджує, що сучасна фізика проявляє інтерес до деяких архаїчних сюжетів прадавньої космології, а окремі філософи, історики чи соціологи в творчості "свої зовні об'єктивні наукові побудови парадоксально поєднують з міфотворчістю різної інтенсивності". Як вважає український філософ, поява й широке поширення міфотворчості чи міфологізації - це характерна риса теперішнього часу, бо цивілізація "змобілізувала величезні людські маси в індустріальні та політичні колективи, тим самим поновила й міфологічні інтенції різних штабів" [12: 387]. Крім того, він указує, що зараз мають поширення не тільки політичні міфи, а й міфи масової культури, тому відбувається їх своєрідна "ритуалізація" і цьому сприяють "технічні засоби масової комунікації". Тобто, дослідником помічено значення ЗМІ, реклами та подібного при створенні й поширенні серед сучасників новітніх міфів або міфологем. Проте складається враження, що він уживає поняття міфотворчості і міфологізації, ніби, синоніми. Таке враження лише посилюється, коли йдеться про "міфи другого покоління" - новітні міфи сучасності, адже вони "породжені новітньою цивілізацією, але знов-таки на тлі давнього міфотворення" [12: 388]. Досить наближеним до поняття міфотворчості, як видається, є ужиток поняття міфотворення. Проте можна припустити, що останнє є більш тривалим процесом та результатом колективної дії, а міфотворчість є, так би мовити, більш локальною та індивідуалізованою.

Вкажемо, що в контексті аналізу сучасної культури, новітнього способу соціального життя Л. Воєводіна дає визначення міфотворчості як іманентної функції людської свідомості й способу відтворення культури в суспільстві, а також засобу соціального конструювання реальності [3]. При цьому міфотворчість розуміється нею, певною мірою, як деструкція соціального, оскільки вплив міфів, на погляд дослідниці, на особистість має місце за умови відсутності точної інформації чи недостатньої інформаційної бази, браку освіти тощо. Тому можна зробити висновок, що подолання вказаних чинників мало б призвести до зникнення міфів із теперішньої суспільної свідомості, що наразі не спостерігається. 3 таких позицій, відтак, важко пояснити феномен існування міфів (чи міфологем) у духовному житті й символічному виробництві сучасного суспільства (політичних, релігійних, рекламно-комерційних, художніх тощо).

Тому зазначимо, що поняття "міфотворчість" і "міфологія" співвідносяться один з одним як такі, що позначають процес, різновид людської діяльності і результат, закріплений у суспільній свідомості. Якщо міфотворчість позначає формування, творення міфів, то міфологія - сукупність останніх. Утім, зазначений зв'язок не розкриває у повному обсязі характер їх співвідношення, оскільки перше явище виступає й способом відтворення культури в суспільстві, а інше - формою суспільного світогляду. На наш погляд, аналіз даного поняття потребує, крім того, розгляду понять, близьких чи дотичних до нього за змістом, насамперед таких як: "міфізація", "міфологізація", "деміфологізація" та з'ясування характеру співвідношення з ним, а ще й звернення до розгляду змістовного насичення такого явища, як міфопоезис.

Зокрема, протилежним за змістом до міфотворчості постає деміфологізація, що розуміється здебільшого явищем, яке полягає в поясненні і раціональному переосмисленні поширеного міфу (міфологеми), а також спільному переживанні його в "поняттях зрілої культури" [11: 565]. Наголошуючи на плідності цієї ідеї, можемо стверджувати, що деміфологізація та міфотворчість (також і міфологізація) постають ніби діалектично поєднаними протилежностями: створені колись міфи у процесі розвитку суспільної свідомості, культури "осмислюються" з позицій цінності, важливості для життя конкретноісторичних груп, i, навіть, можуть згодом втратити значущість. Вони спростовуються системою 
раціональних способів пізнання чи соціальною практикою, але існування конкретного міфу не завжди припиняється в результаті його "викриття" (він може трансформуватися у новий міф чи новітню міфологему). Так, міф про плоску форму Землі (хоча й спростований ще понад п’ять століть тому) у сучасній масовій культурі використовується не тільки в інтернет-ресурсах для зацікавлення і розширення своєї аудиторії. Навпаки, на його основі виникли нові міфи (міфологеми) про віртуальність Всесвіту (останній вважається мегаголограмою) чи паралельні Всесвіти, із якими стикається пересічний читач, блукаючи "світовою павутиною", тобто звертаючись до інформаційного ресурсу Інтернету.

Відповідно, перед теперішнім науковим і філософським світоглядом постало незвичне завдання спростувати такі фіктивні чи поза наукові твердження, витіснивши їх науковою картиною при поясненні світу. Адже в комунікативному просторі XXI століття, особливо через появу Інтернету та мережевої комунікації, виник феномен масового породження і поширення ненаукового знання у суспільній свідомості.

Це може, на нашу думку, мати деструктивні наслідки, хоча б тому, що подібне не сприяє розвитку критичності мислення у сучасної молодої людини, проте сприяє поширенню чуток і неперевіреної інформації та ін. Як слушно вказує Н. Воронова, "міфологічно стереотипне сприйняття масовою свідомістю тих чи інших культурних реалій (соціальних, політичних, естетичних, моральних і т.п.) зумовлює варіативність культурних процесів у різних цивілізаційних системах" [4: 3]. Така варіативність має дуже різні вияви й наслідки для суспільства загалом і життя його окремих груп, прошарків.

Але будь-яка стереотипність людини в сприйнятті світу, діях, оцінках або поглядах є ознакою опертя на шаблонність мислення чи його консерватизм. Тоді породження міфів іноді стимулюється бажанням цього уникнути, а наслідком може стати "а-логіка" людських вчинків чи ж мислення. При дослідженні особливостей міфологізації в сучасному суспільстві й значення в ній міфопоезису О. Поліщук зауважує: "Під а-логікою розуміємо логіку альтернативних вчинків і мотивації людського життя в протиставленні до меркантилізму та утилітаризму. Наприклад, логіка художнього плану, як логіка вчинків художнього персонажа, сама по собі не виступає як а-логіка, найчастіше вона просто інша від логіки вчинків людини у повсякденному житті. Однак вона виступає стимулом для читача або глядача, можливо через незвичність". Тобто, у міфічній площині - як результат художнього мислення автора твору, логіка художнього плану постає "специфічною альтернативою повсякденної, шаблонної логіки вчинків масової людини" [12:40]. Тоді зацікавлене ставлення багатьох сучасників до художніх міфів, породжених популярним мистецтвом й культурою, на наш погляд, $\epsilon$ не тільки наслідком бажання людини розважитися якоюсь "новинкою". Воно можливо виникає через прагнення людини, напевно неусвідомлене, вийти за межі усталеності, однотипності, з одного боку, а з іншого - це протест окремих людей від "втоми" життям, в якому меркантилізм, утилітаризм є особливо цінними для успіху в суспільному житті. Тому при створенні новітніх міфів (міфологем) в рекламній діяльності, як видається, враховується саме подібне прагнення сучасників. Проте комерційна реклама тяжіє, на наш погляд, до міфізації при символічному виробництві, а соціальна реклама намагається спиратися найчастіше на міфотворчість. Остання прагне ніби допомогти сучасникам не тільки усвідомити певну соціальну проблему, але й намагається часто допомагати долати логіку "меркантильної людини" чи втому від прагматичного, утилітарного ставлення до життя, в якому міжособистісне спілкування та дружні стосунки цінуються мало.

Відтак хочеться наголосити, що в наш час міфологічний компонент суспільної свідомості й думки став вагомим чинником для життя більшості сучасників (через вплив ЗМІ, масових комунікацій та реклами, популярної літератури чи кіномистецтва, художньої анімації тощо).

Висновки. При спробі концептуалізації проблеми міфотворчості в сучасному комунікативному, інформаційному просторі, як підсумок, вкажемо наступне.

1) Існує потреба термінологічного розрізнення понять: "міфотворчість", "міфотворення", "міфологізація", "міфізація", які вживаються науковцями при розгляді творення і поширення міфів, як архаїчних, так і новітніх. Нами пропонується звернути увагу на міфотворчість як усвідомлене продукування з боку людини конкретних новітніх міфів, точніше міфологем, наприклад 3 виробничих потреб, як це робить сучасний сценарист чи ж письменник. Тоді як міфотворення варто розглядати, на наш погляд, досить тривалим процесом із створення низки міфів, а ще й, крім того, результатом колективної дії. Тобто, міфотворчість має, так би мовити, більш локальний, індивідуалізований характер, коли говоримо про витоки чи породження новітнього міфу (міфологеми). Тому коли йдеться, наприклад, про появу останніх для рекламування товару або при створенні мистецької інновації в популярній культурі, було б доречним вживати поняття міфотворення.

Щодо розрізнення міфотворчості і міфізації, то було б доречно звернути увагу, на нашу думку, на позитивний чи негативний наслідок появи конкретного новітнього міфу для суспільного життя. Якщо він створений для розваги, гри і не має негативних наслідків для людського життя, тоді варто уживати, на наш погляд, поняття міфотворчості. Коли ж має місце будь-яка соціальна деструкція, негативний наслідок - мова йде, як вважаємо, про явище міфізації у суспільному житті, коли при символічному 
виробництві створюється міфологеми (чи ж ідеологема), яка нав'язується громадській думці при комунікації.

2) Створення новітніх міфів (міфологем) та їх масове поширення у ЗМІ, рекламі або популярній літературі й кінематографі, на наш погляд, понижує "поріг адекватності" при сприйнятті повідомлень та різних інформаційних потоків, циркулюючих в теперішньому суспільстві. На наш погляд, це не сприяє критичності мислення у багатьох сучасників. Крім того, міфотворчість та міфізація у теперішньому комунікативному просторі стають все більш різноманітними за вираженням, оскільки не тільки спілкування у мережевих спільнотах чи "просторі Нета" є джерелом появи або ж засобом швидкого поширення новітніх міфів. Потужно їх зараз творить соціальна, політична і комерційна реклама, маючи широкі можливості до поширення такого незвичного продукту при символічному виробництві сучасного соціуму (особливо завдяки такому носію як телебачення чи Інтернет-ресурс).

3) Відтак, перспективу подальших досліджень має складати копітке вивчення сучасною філософською думкою, зокрема, і гуманітаристикою, в цілому, проблеми ролі рекламної міфізації для суспільства XXI століття. А також існує, на наш погляд, необхідність аналізу рекламної міфотворчості, коли мова йде про соціальну рекламу (наприклад в нашій країні це необхідно для популяризації захисників Вітчизни від зовнішньої агресії). Крім того, вбачаємо необхідність розгляду значущості цих явищ в комунікації, світогляді, цінностях чи ціннісних орієнтаціях сучасного суспільства.

\section{СПИСОК ВИКОРИСТАНИХ ДЖЕРЕЛ ТА ЛІТЕРАТУРИ}

1. Барт Р. Миф сегодня / Р. Барт // Избранные работы : Семиотика. - Поэтика. - М. : Прогресс, 1994. - С. 2 130.

2. Бондарь О. П. Мифотехнологии в практике социальных коммуникаций / О. П. Бондарь // Пресс-служба. 2008. - № 6. - С. 34-38.

3. Воеводина Л. Н. Мифотворчество как феномен современной культуры / Лариса Николаевна Воеводина : автореферат дис. ... на соискание ученой степени доктора философских наук : спец-сть 24.00.01 "Теория и история культуры". - М., 2002. - 41 с.

4. Воронова Н. И. Неомиф в духовной культуре современной России: этнонациональный аспект : дис. ...канд. филос. наук : 24.00.01 / Воронова Наталья Игоревна ; Российский госпедун-т имени А. И. Герцена. - СПб., 2007. $-270 \mathrm{c}$.

5. Дубицкая В. П. Телевидение. Мифотехнологии в электронных средствах массовой информации / В. П. Дубицкая ; Ин-т социологии РАН. - М. : Изд-во Ин-та социологии РАН, 1998. - 144 с.

6. Кассирер Э. Техника современных мифов / Э. Кассирер // Вестник Московского университета. - Сер. 7 : Философия. - 1990. - № 2. - С. 59-60.

7. Поліщук О. Етос та естезис neomythos в сучасному інформаційному просторі (до проблеми змісту естетичної інформації) / Олена Поліщук // Мандрівець. - 2015. - № 6. - С. 59-62.

8. Sapeńko R. Estetyka - mit - neomit / Roman Sapeńko // Mitologizacja kultury w polskiej i iberyjskiej twórczości artystycznej. - Zielona Góra, 2015. - S. 55-70.

9. Великий тлумачний словник сучасної української мови / [уклад. і голов. ред. В. Т. Бусел]. - Київ, Ірпінь : ВТФ "Перун", 2009. - 1736 с.

10. Скуратівський В.Міф / В. Скуратівський // Філософський енциклопедичний словник. - Київ, 2002. С. 386-387.

11. Скуратівський В. Міфологія / В. Скуратівський // Філософський енциклопедичний словник. - Київ, 2002. С. 387-388.

12. Философский словарь / И. В. Андрущенко, О. А. Вусатюк, С. В. Линецкий, А. В. Шуба. - Київ : А. С. К., 2006. - $1056 \mathrm{c}$.

13. Polishchuk O. Mythopoesis i mitologizacja jako fenomeny współczesnej kultury / Olena Polishchuk // Mitologizacja kultury w polskiej i iberyjskiej twórczości artystycznej. - Zielona Góra, 2015. - S. 33-42.

\section{REFERENCES (TRANSLATED \& TRANSLITERATED)}

1. Bart R. Mif segodnia [Myth Today] / R. Bart // Izbrannyie raboty : Semiotika. Poetika. [Selected Works : Semiotics. Poetics]. - M. : Progress, 1994. - S. 72-130.

2. Bondar O. P. Mifotehnologii v praktike sotsialnykh kommunikatsii [Mythotechnologies in the Practice of Social Communications] / O. P. Bondar // Press-sluzhba [Press Office] - 2008. - № 6. - S. 34-38.

3. Voevodina L. N. Mifotvorchestvo kak fenomen sovremennoi kul'tury [Myth-Making as a Phenomenon of Modern Culture] / Larisa Nikolaevna Voevodina : avtoreferat dis. ... doktora filosofskikh nauk : spets-st 24.00.01 "Teoriia i istoriia kul'tury". - M., 2002. $-41 \mathrm{~s}$.

4. Voronova N. I. Neomif $\mathrm{v}$ dukhovnoi kul'ture sovremennoi Rossii : etnonatsionalnyi aspect [Neomyth in the Spiritual Culture of Modern Russia : the Ethno-National Aspect] : dis. ...kand. filos. nauk : spetsialnost' 24.00 .01 Teoriia i istoriia kul'tury / Voronova Natalia Igorevna ; Rossiiskii gospedun-t imeni A. I. Gertsena. - SPb., 2007. $270 \mathrm{~s}$.

5. Dubitskaya V. P. Televidenie. Mifotehnologii v elektronnykh sredstvakh massovoi informatsii [TV. Mythology in Electronic Media] / V. P. Dubitskaya ; In-t sotsiologii RAN. - M. : Izd-vo In-ta sotsiologii RAN, 1998. - 144 s

6. Kassirer E. Tehnika sovremennykh mifov [Technique of Modern Myths] / E. Kassirer // Vestnik Moskovskogo universiteta [Moscow University Bulletin]. - Ser. 7 : Filosofiia. - 1990. - № 2. - S. 59-60. 
7. Polischuk O. Etos ta estezis neomythos v suchasnomu Informatsiinomu prostori (do problemi zmistu estetichnoi informatsii) [Ethos and Neomythos Estezis in the Modern Information Space (until Problems and Aesthetic Information)] / Olena Polischuk // Mandrivets. - 2015. - № 6. - S. 59-62.

8. Sapeńko R. Estetyka - mit - neomit / Roman Sapeńko // Mitologizacja kultury w polskiej i iberyjskiej twórczości artystycznej. [Mythologization of Culture in Polish and Iberian Artistic Creation]. - Zielona Góra, 2015. - S. 5570.

9. Velikii tlumachnii slovnik suchasnoi ukrainskoi movy [The Great Dictionary of the Ukrainian Language] / [uklad. i golov. red. V. T. Busel]. - Kyiv, Irpin' : VTF "Perun", 2009. - 1736 s.

10. Skurativskiy V. Mif [Myth] / V. Skurativskiy // Filosofskiy entsiklopedichniy slovnik. [Philosophical Encyclopedic Vocabulary]. - Kiyiv, 2002. - S. 386-387.

11. Filosofskiy slovar' [Philosophical Dictionary] / I. V. Andruschenko, O. A. Vusatyuk, S. V. Linetskiy, A. V. Shuba. - Kiyiv : A. S. K., 2006. - 1056 s.

12. Skurativskiy V. Mifologiia [Mythology] / V. Skurativskiy // Filosofskyi entsiklopedichnyi slovnyk [Philosophical Encyclopedic Vocabulary]. - Kiyiv, 2002. - S. 387-388.

13. Polishchuk O. Mythopoesis i mitologizacja jako fenomeny współczesnej kultury [Mythopoesis and Mythologization as Phenomena of Contemporary Culture] / Olena Polishchuk // Mitologizacja kultury w polskiej i iberyjskiej twórczości artystycznej. - Zielona Góra, 2015. - S. 33-42.

\section{Слюсар Н. В. Мифотворчество в коммуникативном пространстве: к вопросу концептуализации проблемы.}

Осуществлен анализ феномена мифотворчества, что происходит в современной коммуникации благодаря популярной литературе, киноискусству, анимаџии и т.n. На основе рассмотрения содержательного насыщения таких понятий, как "мифологизация", "демифологизация", "мифология" и

"мифизация", автор пришел кмысли, что они фиксируют неодинаковые явления при создании или распространении мифов, в том числе и новейших мифов, которые широко представлены в современном коммуникативном пространстве благодаря СМИ, рекламе, массовой культуре и популярному искусству, политической деятельности различных институтов современного общества.

Предложено рассматривать мифотворчество сознательным производством, созданием со сторонь человека конкретных новейших мифов, точнее мифологем, например, из производственных потребностей в массовой культуре, популярном искусстве. Также утверждаем, что в отличие от мифизации, мифотворчество имеет положительное значение для духовной жизни современного обшества.

Утверждаем, что одной из весомых причин существования мифотворчества это человеческое желание выходить за предель повседневности, чтобы избежать скуки, усталости и развлечься. Еще одним важным ее стимулом является стремление отойти, хотя бы на время, от логики утилитаризма, меркантилизма, которая активно пропагандируется в современном обществе.

Ключевые слова: новейший миф, мифотворчество, мифологизация, коммуникативное пространство, общественное сознание.

\section{Slyusar M. V. Mythmaking in the Communicative Space: To the Issue of Conceptualizing the Problem.}

The analysis of the phenomenon of mythmaking, which takes place in modern communication due to popular literature, cinema and animation, etc., is analyzed. Based on the consideration of content saturation of concepts such as "mythologization", "demythologization", "mythology" and "mythization", the author came to the conclusion that they capture unequal phenomena when creating or spreading myths, including the most recent myths that are widely represented in the modern communicative space through mass media, advertising, mass culture and popular art, political activities of various institutions of modern society.

It is proposed to consider mythmaking by conscious production, creation by the person of specific newest myths, more precisely mythological, for example, from the production needs in mass culture, popular art. We also

argue that, unlike mythology, mythmaking has a positive impact on the spiritual life of modern society.

We argue that one of the most important reasons for the existence of mythmaking is the human desire to go beyond the limits of everyday life, to avoid boredom, fatigue and fun. Another important incentive is the desire to withdraw, at least for some time, from the logic of utilitarianism, mercantilism, which is actively promoted in modern society.

Key words: modern myth, myth-making, mythologization, information space, social consciousness. 